\section{Moderne kognitiv terapi}

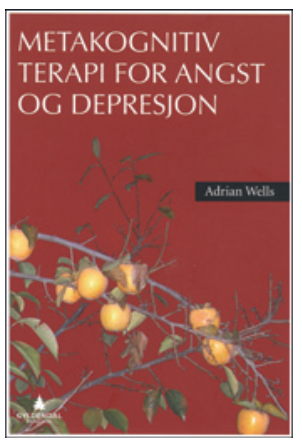

Adrian Wells

Metakognitiv terapi for angst og depresjon

347 s, tab, ill. Oslo: Gyldendal Akademisk,

2011. Pris NOK 435

ISBN 978-82-05-41769-4

Dette er en norsk oversettelse av en bok som allerede har kommet i flere utgaver på engelsk. Psykiatri og psykologi er ikke eksakte vitenskaper, og de lærde strides både om teori og praksis. Desto mer gledelig er det når psykoterapi utvikles på bakgrunn av eksperimentelle studier og deretter testes i kliniske randomiserte studier. Dette er tilfellet med metakognitiv terapi, som er en videreutvikling av kognitiv terapi.

Hensikten er å gi en praktisk innføring i metakognitiv terapi, og målgruppen er terapeuter som ønsker å lære seg metoden. I de første kapitlene beskriver forfatteren hvordan man initialt i terapien drøfter med pasienten hvilke positive og negative antakelser de har om bekymring og grubling, og i hvor stor grad de er fanget $i$ en trusselovervåkning. De positive forestillingene pasienter ofte har om verdien av grubling og bekymring, ses på som viktige, opprettholdende faktorer for de fleste psykiske lidelser.

I de neste kapitlene forklarer forfatteren hva oppmerksomhetstrening og spesielt øvelser i såkalt «frakoblet oppmerksomhet» er, noe som kan være nyttig, men som ikke er en forutsetning for at metakognitiv terapi skal ha ønsket effekt. Generalisert angstlidelse, posttraumatisk stresslidelse, tvangslidelse og alvorlig depresjon omtales nøye hver for seg, med en praktisk gjennomgang av kasusbeskrivelse og behandlingsopplegg, inkludert tilbakefallsprofylakse. Til slutt presenterer forfatteren kunnskapsgrunnlaget for metakognitiv terapi. Som vedlegg finner leseren en rekke skjemaer og behandlingsplaner.

For terapeuter som allerede behersker kognitiv terapi, vil denne boken kunne utvide og skjerpe terapeutiske ferdigheter, og den er så praktisk lagt opp at man godt kan benytte den som en behandlingsmanual. For psykoterapeuter som ikke har bestemt seg for hvilken terapeutisk retning de vil spesialisere seg i, vil boken være en verdifull innføring $i$ en av de mest lovende og forskningsmessig aktive retninger innen moderne kognitiv terapi.

All terapi krever mye øvelse, men i tillegg til kursing og personlig veiledning, vil denne boken kunne være både inspirerende og hjelpe terapeuten til å holde fokus i terapi. Man kan spare mye tid dersom man fokuserer mer på hvordan pasienten forholder seg til og tenker omkring det som skjer i livet eller eget sinn, enn på hva som skjer. Boken anbefales på det varmeste for alle som er interessert i å lære mer om psykoterapi generelt og kognitiv terapi spesielt.

\section{Klinisk sosialmedisin og rehabilitering}

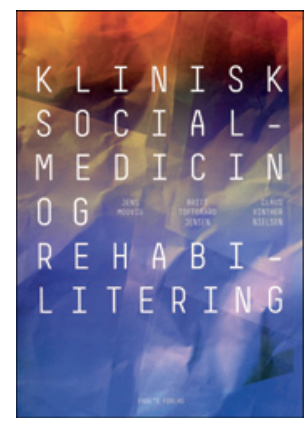

Klaus Vinter Nielsen, Jens Modvig,

Britt Toftegaard Jensen, red.

Klinisk socialmedicin og rehabilitering

304 s, tab, ill. København: FADL's Forlag,

2011. Pris DKK 400

ISBN 978-87-7749-597-7

Den primære målgruppen er medisinstudenter, men også studenter innen andre helsefag i Danmark.

Boken har 22 kapitler. I de første sju gjennomgår forfatterne generelle temaer innen faget. Deretter følger kapitler knyttet til de tre livsfasene barn, voksne og eldre. I siste del omtaler de utvalgte sårbare grupper, fra hjemløse og voldsofre til sårbare gravide. Et standardisert oppsett med disposisjon i starten av hvert kapittel, samt en rekke undertitler og rammetekster, gjør det lett å orientere seg i stoffet. Noen få diagrammer, tabeller og skisseaktige figurer har begrenset verdi.

I Danmark har man en legespesialitet for klinisk sosialmedisin, men ikke for rehabilitering. Det sistnevnte omtales som et tverrfaglig arbeidsområde. Forfatterne begynner med å slå fast at «klinisk socialmedicin er rehabilitering», og at den omfatter legens oppgaver innen rehabiliteringsfeltet. Vi ser her klare forskjeller mellom Danmark og Norge. Hos oss førte oppbyggingen av attføringsmedisinen etter krigen frem til opprettelsen av en spesialitet i klinisk sosialmedisin fra 1958. I 1986 forsvant denne inn i spesialiteten for fysikalsk medisin og rehabilitering, mens sosialmedisinen lever videre som et akademisk fag med et befolkningsrettet mer enn et pasientrettet perspektiv. En sammenlikning mellom denne boken og den nyeste norske læreboken i sosialmedisin illustrerer godt denne ulikheten (1).

Når boken i tillegg er sterkt preget av dansk lovgivning, helsetjenesteoppbygging, sosialvesen og kulturell tradisjon, vil den ha begrenset relevans som lærebok i Norge. Det betyr ikke at den er uinteressant. Den tar opp enkelte temaer som ikke er godt dekket i norske lærebøker. Det er for eksempel et godt kapittel om torturofre, som gir en god innføring i en problematikk som er høyst aktuell også i vårt land.

\section{Kristian Hagestad}

Fylkesmannen i Vest-Agder

Kristiansand

\section{Litteratur}

1. Hagestad K. Grunnbok i sosialmedisinsk praksis, teori og ideologi. Anmeldelse av: Mæland JG, Haug K, Høyer G et al. Sosialmedisin. Tidsskr Nor Legeforen 2011; $131: 2264$ 